\title{
Lead Bioaccumulation in Root and Aerial Part of Natural and Cultivated Pastures in Highly Contaminated Soils in Central Andes of Peru
}

\author{
Jorge Castro Bedriñana ${ }^{*}, 1$, Doris Chirinos Peinado ${ }^{1}$, Richard Peñaloza-Fernández ${ }^{2}$ \\ ${ }^{1}$ Universidad Nacional del Centro del Perú (UNCP), Huancayo, Peru \\ ${ }^{2}$ Universidad Nacional Agraria La Molina, Peru
}

A R T I C L E I N F O

Article history:

Received: 21 November, 2019

Accepted: 25 February, 2020

Online: 09 March, 2020

Keywords:

Heavy metals

Smelting

Soil

Pastures

Transfer factor

Particulate material

\begin{abstract}
A B S T R A C T
Lead concentration on surface soil $(0-20 \mathrm{~cm})$, root and aerial part of natural and cultivated pastures were evaluated, in the rainy season (March 2018), collected in 20 sites of a rural community located $20 \mathrm{~km}$ from the La Oroya metallurgical complex, which has been emitting to the environment particulate material with heavy metals since 1922. Lead concentration was determined by flame atomic absorption spectrometry. The data was statistically processed in SPSS 23. Lead levels in the soil, root and aerial part of the cultivated pastures were $224.75 \pm 39.41,169.13+58.79$ and $20.73 \pm 2.52 \mathrm{mg} / \mathrm{kg}(\mathrm{p}$ $<0.01)$. In natural pastures values were $210.87 a \pm 40.37,184.36 b+52.66$ and $19.47 c \pm$ $3.12 \mathrm{mg} / \mathrm{kg}(\mathrm{p}<0.01)$. There are no differences between cultivated and natural pastures. Lead transfer factor from soil to root of cultivated and natural pastures was 0.75 and 0.87 . Lead transfer factor value from soil to aerial part of cultivated and natural pastures was 0.092 in both. High lead content in soil and aerial part of the pastures used as food for high Andean cattle is a public health problem; livestock products produced in these soils would not be fit for human consumption.
\end{abstract}

\section{Introduction}

The important mining activity for Peru [1] involves the emission of particulate matter (PM) loaded with heavy metals, which are transported by air [2] and deposited in water and soil, then transferred to pastures, causing adverse effects on animals and human health [3-6].

Lead soil contamination affects its quality, destroys the power of self-purification through biological regeneration, decreases the normal growth of soil microorganisms, alters biodiversity and decreases crop yields [7].

Due to the long half-life and high potential for bioaccumulation, lead is available to grass roots causing damage to the same plant [8] generating a highly contaminated biomass with serious consequences for human health [9-13]. Lead (Pb) toxicity affects the central nervous system, cardiovascular, digestive and urogenital system, and causes different types of cancer [14-16].

\footnotetext{
*Jorge Castro-Bedriñana, Av. Mariscal Castilla 3909, El Tambo-Huancayo, +51 964408057 \& jorgecastrobe@yahoo.com
}

The $\mathrm{Pb}$ absorption is affected by the concentration of other metals, $\mathrm{pH}$ and organic matter content [17] and bioaccumulation of chemical elements in plants depends on their concentrations in soil [10]. Bioaccumulation of toxic heavy metals pose a threat to human health, induce renal tumors, reduce cognitive, development, and increase blood pressure and cardiovascular diseases risk for adults [18, 19].

The transfer factor (TF), is the relationship between the concentration of metal in the aerial part of the plant and that of the soil $[20,21]$. The TF quantifies the metal bioavailability and is an indicator of the extent of metal mobility $[20,22]$. The TF is the key parameter of the heavy metal accumulation in plants, because it is the main pathway of human exposure to soil contamination by heavy metal accumulation [20].

Poly-metallic transformation of copper, zinc, silver, lead, indium, bismuth, gold, selenium, tellurium and antimony, emits toxic substances into the environment polluting the ecosystem [23].

In the central region of Peru, for more than 90 years, soils have been contaminated by metallurgical emissions of fine particulate 
material, rich in lead and other heavy metals [24], which have been deposited in the soil and they are available for plants $[25,26$, 17]; in this case, $\mathrm{Pb}$ bioaccumulates in the pastures consumed by cattle, sheep and South American camelids.

Analysis of the soil surface layer (between 0 to $20 \mathrm{~cm}$ ) will provide valuable information to study the dynamics of contamination of $\mathrm{Pb}$ from soil to plant [27].

A main activity of families living in Andean communities located near the metallurgical complex is the raising of sheep, alpacas and cows in large areas of natural pastures, and there is no information on the lead content of pastures consumed by these high Andean cattle.

This research contributes information on the soil-root-plant relationship, by determining the concentration of $\mathrm{Pb}$ in soil, root and natural and cultivated pastures and their transfer factors (Figure 1), contrasting the content of $\mathrm{Pb}$ in soil and grass of the study with levels of environmental quality safety [28, 29].

Results represent the most up-to-date cut in the content of $\mathrm{Pb}$ in the surface soil and pastures of a highly contaminated area of the central highlands of Peru. This information can be used to establish a better regulation of environmental and human health protection by $\mathrm{Pb}$ contamination.

Figure 1 shown the sequence of the pasture contamination by heavy metals. Self-created model

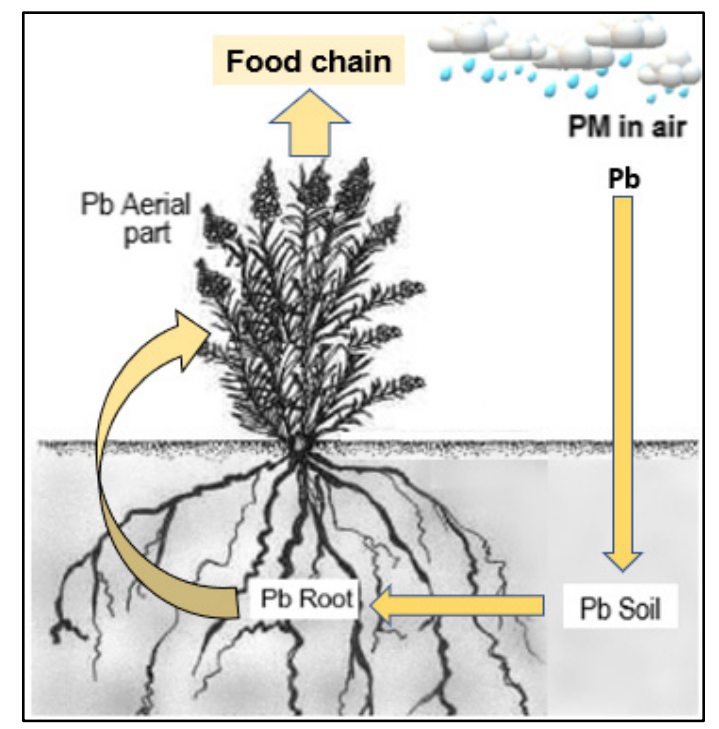

Figure 1: Sequence of pasture contamination by lead from metallurgical emissions. PM: Particulate Material (with heavy metal and other pollutants)

\section{Materials and methods}

\subsection{Study area}

Peasant community "Purísima Concepción de Paccha" (CCP-LO), of Yauli province, Junín-Peru, is situated between South Latitude $11^{\circ} 31^{\prime} 03^{\prime \prime}$ and West Longitude $75^{\circ} 53^{\prime} 58^{\prime \prime}$ (altitude 3,700) and located $10.2 \mathrm{~km}$ from metallurgical complex La Oroya (Figure 2), industry dedicated to poly-metallic transformation (copper, zinc, silver, lead, indium, bismuth, gold, selenium, tellurium and antimony), that emits fine particulate material (PM), loaded with heavy metals that pollute the ecosystem for more than nine decades $[23,24]$. $\mathrm{PM}$ rich in $\mathrm{Pb}$ and other heavy metals is deposited in the soil and water resources, and being easy transferred to the plants $[25,26,17]$. Figure 2 shown the geographical location o the CCP-LO.

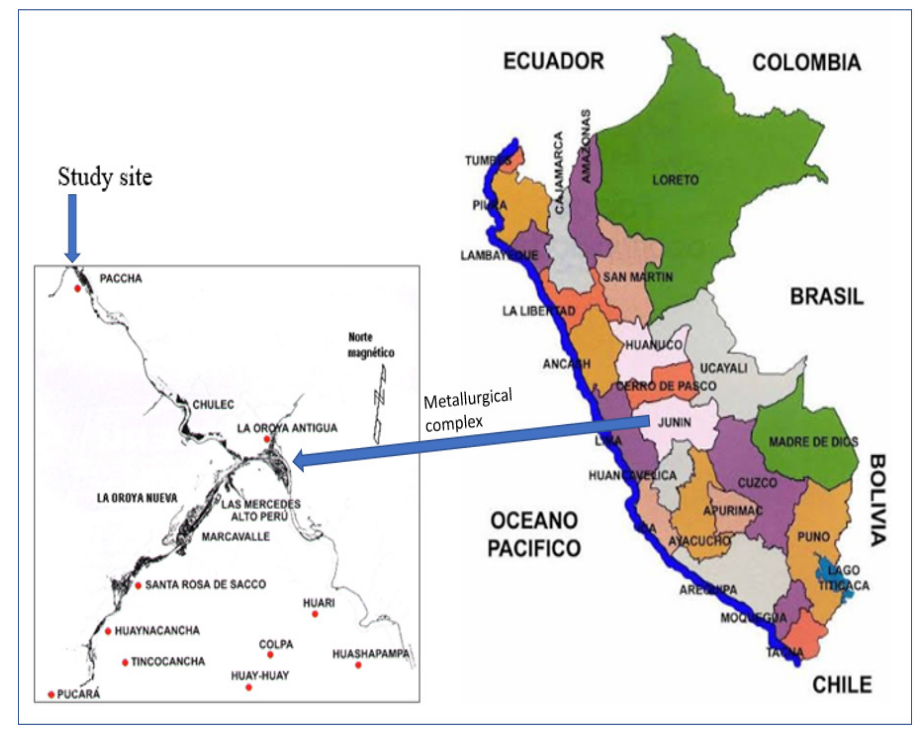

Figure 2. Geographical location of the peasant community of Paccha, study site

Sampling of soil, root and aerial part of natural and cultivated pastures was carried out in the rainy season (November to March 2018). These pastures are used to feed high Andean cattle (sheep $>$ alpacas $>$ cows). Natural grasses are mainly composed of Festuca dolichophylla, Piptochaetium faetertonei, Bromus catharticus, Bromus lanatus and Calamagrostis heterophylla, and small extensions of cultivated pastures associated with Lolium perenne and Trifolium repens. CCO-LO has approximately 6000 ha of communal land with natural pastures (NP) and six hectares of cultivated pastures (CP), distributed in different grazing sites to feed sheep, cows and alpacas. CP in study site was installed 15 years ago. The productive and nutritional quality of both pastures is poor.

Quantification of lead in samples soil, root and aerial part of the plants were carried out in the Baltic Control SAC Laboratory, accredited by the National Institute of Quality - INACAL, Peru.

\subsection{Sample collection}

The soil and grass samples collected for the study approximately correspond to 1 ha of natural pastures (NP) and 1 ha cultivated pastures (CP) (Figure 3).

In March 2018 (rainy season), a total of 60 samples were taken (20 parallel samples of soil, root and aerial part of natural and cultivated pastures, 10 samples for each pasture type) at twentyfive-meter zigzag intervals. Samples were taken from upper soil layer $(0-20 \mathrm{~cm})[30,31,32]$ of 1 ha of NP and 1 ha of CP near the CCP-LO stable (Figure 3). Five random subsamples taken of approximate area of $1 \mathrm{~m}^{2}$ were mixed until $0.5 \mathrm{~kg}$ soil sample was completing in a polythene bag and then taken to the laboratory. Soil samples were air dried for 48 hours, and then sieved with 2 $\mathrm{mm}$ mesh to remove gravel, stone and other materials prior to analysis. Sample collection details are provided in [27, 33]. 


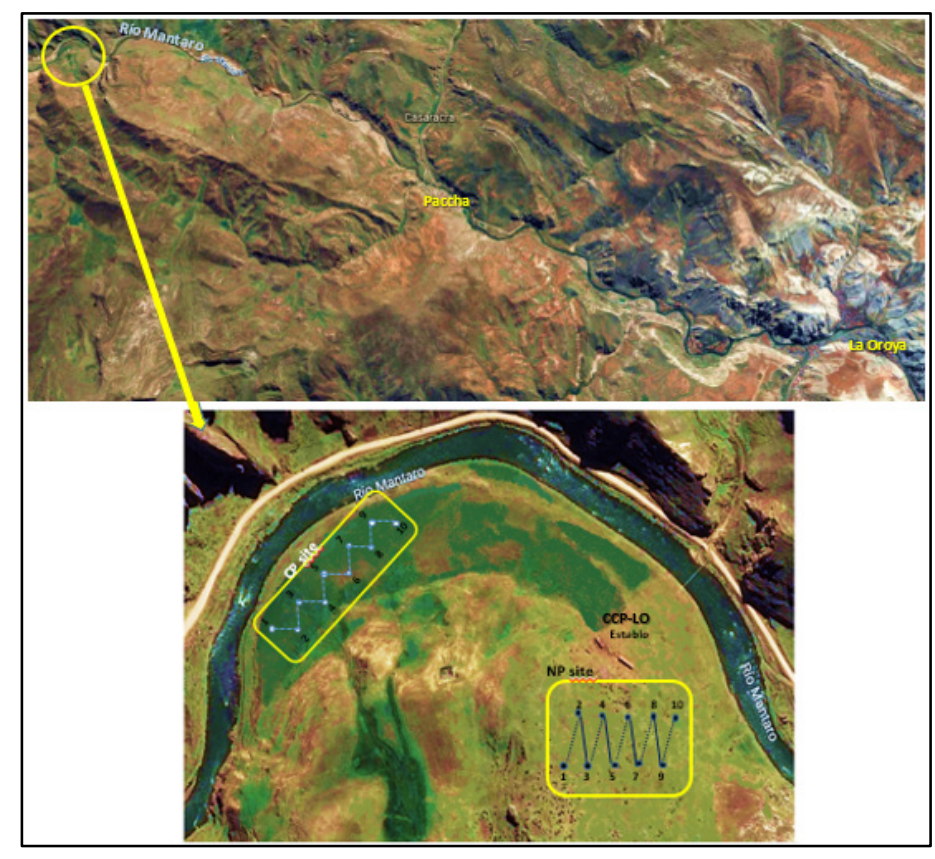

Figure 3. Soil and pasture sampling sites in CCP-LO. The image above is the map of the Paccha-Junín district, and shows the road from the city of La Oroya to Paccha; The bottom image is the sampling sketch in natural and cultivated pastures areas (NP $\mathrm{n}=10 ; \mathrm{CP} \mathrm{n}=10)$. La Oroya city is located $183.4 \mathrm{~km}$ from Lima (Capital of Peru) by the central highway. There is located the polymetallic metallurgical complex. Paccha District is located $10.2 \mathrm{~km}$ from La Oroya, and the "Comunidad Purísima Concepción de Paccha" (CCP-LO), where the cow stable is located, is approximately 40 minutes away by road. CCP-LO is characterized by its high altitude $(3900-4500)$ and low temperatures $\left(-3^{\circ} \mathrm{C}\right.$ to $\left.11^{\circ} \mathrm{C}\right)$. Community population: 315 families.

The forage samples were collected from the same place where soil samples were collected and on which the cows were grazing. The forage samples were divided into root and aerial part [33] and placed in paper bags to take to the laboratory.

\subsection{Lead concentration quantification}

For sample digestion according to USEPA method 3050B (SW-846) to extract the metals, 1 gram of the dried sieved soil was digested with repeated additions of concentrated nitric acid $\left(\mathrm{HNO}_{3}\right)$ and hydrogen peroxide $\left(\mathrm{H}_{2} \mathrm{O}_{2}\right)$. Hydrochloric acid $(\mathrm{HCl})$ was added to the initial digestate and the sample is refluxed. The digestate was diluted to a final volume of $100 \mathrm{~mL}$ [34]. Lead concentration was determined by flame atomic absorption spectrometry (FLAA), following the AOAC-Official Method 975.03 protocol [35]. Analysis were in duplicate and the lead concentration units are expressed in $\mathrm{mg} / \mathrm{kg}$. To determine the concentration of $\mathrm{Pb}$ in the roots and aerial part of the pastures the same analysis procedure was followed.

\section{Summary process:}

1. Homogenize and eliminate foreign material

2. Sift the sample $2 \mathrm{~mm}$.

3. Dry the sample in an oven $\left(30-35^{\circ} \mathrm{C} / 4 \mathrm{~h}\right)$

4. Bag the subsamples.

5. Weigh $1 \mathrm{~g}$ of the sample and transfer to a $250 \mathrm{~mL}$ beaker.

6. Add $10 \mathrm{~mL}$ of $\mathrm{HNO}_{3}(1: 1)$ and heat without boiling at $95+$ $-5^{\circ} \mathrm{C}$ for $15 \mathrm{~min}$.

7. Add $5 \mathrm{~mL}$ of $\mathrm{HNO}_{3}$ (cc) until a complete reaction is achieved and concentrate up to $5 \mathrm{~mL}$.
8. Add $2 \mathrm{~mL}$ of water and $3 \mathrm{~mL} \mathrm{HCl}$ (minimum effervescence) and concentrate up to $5 \mathrm{~mL}$

9. Filter and refine at a $100 \mathrm{~mL}$ vial. Apply the quality controls of the sample.

10. Calibration curve building and analysis the sample by flame atomic absorption spectroscopy (FLAA).

11. Report results in units of $\mathrm{mg} / \mathrm{kg}$.

Quality Control: Method blank (BK), Duplicate Sample (DM) and Control Pattern (PC) were performed in high and low range for every 15 samples. For the calibration curve, Pb Sigma-Aldrich $986+-4 \mathrm{mg} / \mathrm{kg}$ was used as standard. In addition, the $\mathrm{Pb}$ detection limit was $0.2 \mathrm{mg} / \mathrm{kg}$.

\subsection{Statistical analysis}

Information was processed in SPSS 23. Descriptive statistics were used and variance analyzes were conducted for lead contents in the soil, root and aerial part of the plant, with Tukey significance tests at a confidence level $P<0.05$. To determine the difference in means between $\mathrm{Pb}$ in soil and grass with the maximum permissible limits, " $t$ " tests were performed for a single sample. Maximum limits used for soil and grass were 70 and 30 $\mathrm{mg} / \mathrm{kg}$.

\section{Results}

\subsection{Lead concentration in the soil, root and aerial part of pastures}

The $\mathrm{Pb}$ concentrations in descending order were soil $>$ root $>$ grass $(\mathrm{p}<0.01)$. The data had normal distribution patterns. There were no statistical differences between natural pastures (NP) and cultivated pastures (CP) (Table 1, Figures 1, 2).

Table 1. Pb concentration in soil, root and aerial part of PN and PC in livestock area near the La Oroya Metallurgical Complex ( $\mathrm{mg} / \mathrm{kg})$.

\begin{tabular}{lrrrrr} 
Lead content & Average & $\begin{array}{c}\text { Standard } \\
\text { Deviation }\end{array}$ & Variance & Min. & Max. \\
\hline PN soil & $210.87 \mathrm{a}$ & 40.37 & 1629.45 & 131,76 & 264.92 \\
PC soil & $224.75 \mathrm{a}$ & 39.41 & 1553.38 & 171.12 & 284.13 \\
PN root & $184.37 \mathrm{~b}$ & 52.66 & 2773.48 & 102.92 & 251.49 \\
PC root & $169.13 \mathrm{~b}$ & 58.79 & 3456.45 & 102.73 & 263.61 \\
Aerial part-PN & $19.46 \mathrm{c}$ & 3.12 & 9.75 & 14.55 & 23.81 \\
Aerial part-PC & $20.73 \mathrm{c}$ & 2.51 & 6.32 & 16.65 & 23.88 \\
\hline
\end{tabular}

Average values with different letters vary statistically $(P<0.05)$

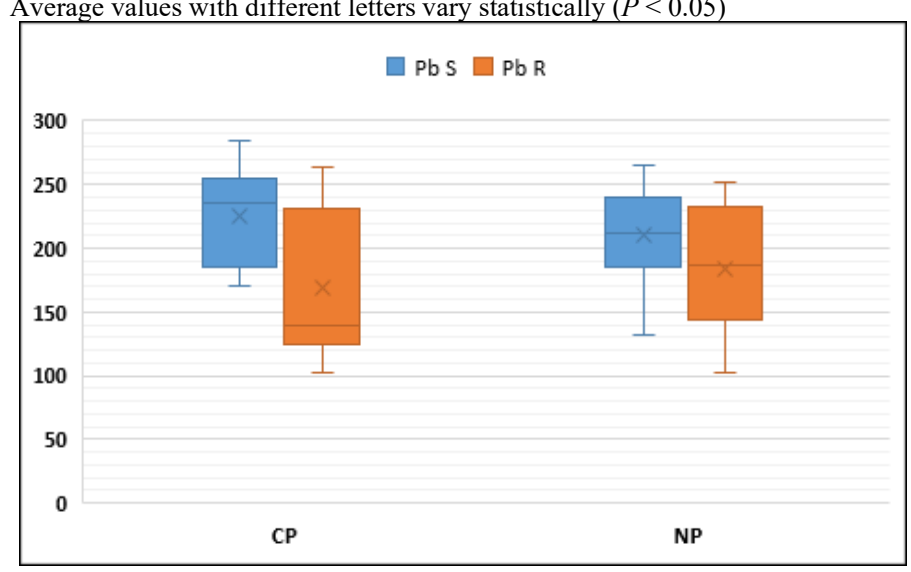

Figure 4. $\mathrm{Pb}$ content in the soil and root of cultivated and natural pastures $(\mathrm{mg} / \mathrm{kg})$ 
$\mathrm{Pb}$ S: Soil $\mathrm{Pb}$ content, $\mathrm{Pb}$ R: Root $\mathrm{Pb}$ content, $\mathrm{CP}$ : Cultivated pastures, NP: Natural pasture

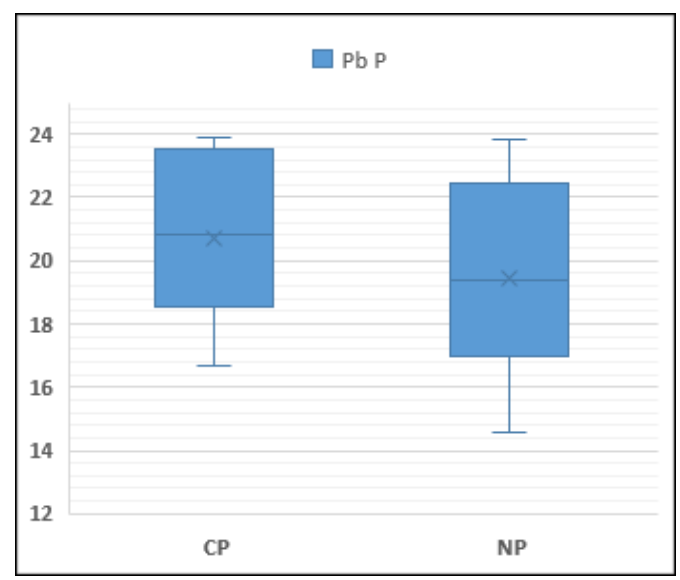

Figure 5. $\mathrm{Pb}$ content in aerial part of cultivated and natural pastures CP: Cultivated pastures, NP: Natural pasture

\subsection{Transfer of $\mathrm{Pb}$ from soil to the root and aerial part of pastures}

The transfer factors of soil $\mathrm{Pb}$ to the root of $\mathrm{CP}$ and $\mathrm{NP}$ were 0.75 and 0.87 . The transfer factor of soil $\mathrm{Pb}$ to the aerial part of $\mathrm{CP}$ and NP was 0.092 for both.

In this study, the percentage of $\mathrm{Pb}$ transfer from the soil to the aerial part of the grasslands was $9.2 \%$ (Table 2, Figure 3), a percentage nine times higher than that reported in conditions of less pollution [9].

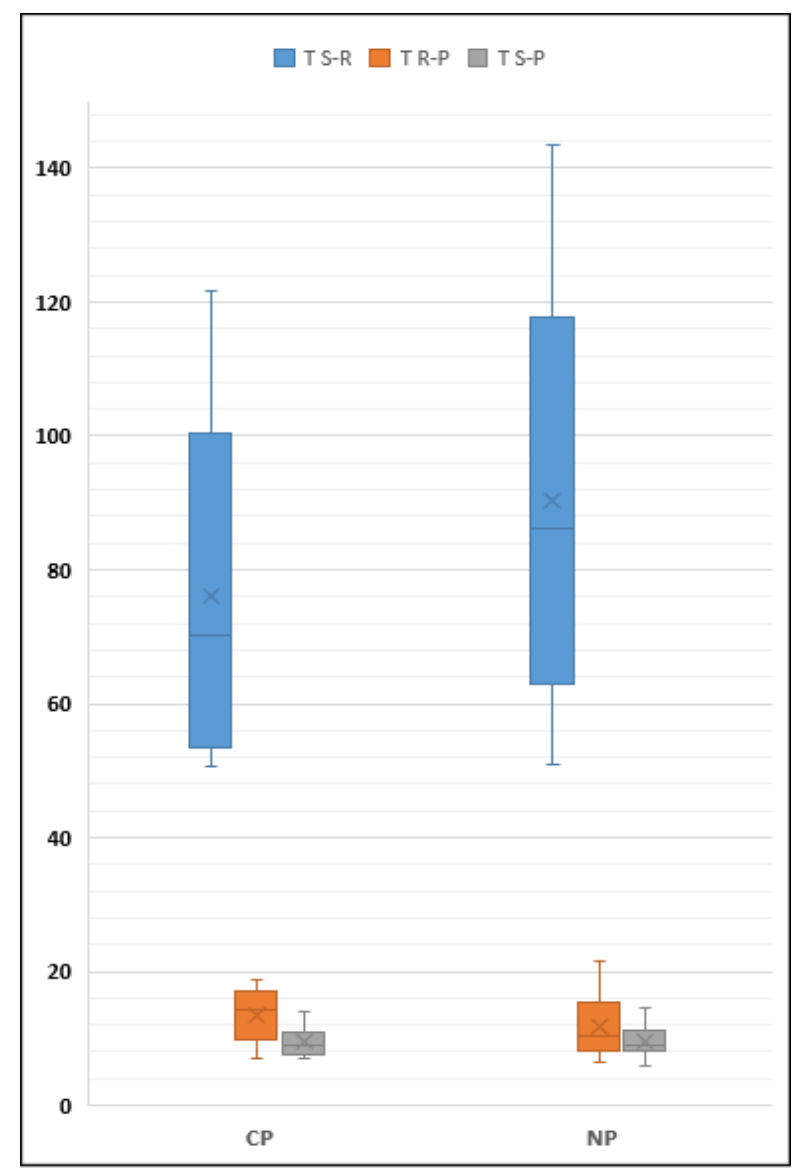

Figure 6. $\mathrm{Pb}$ transfer percentages in NP and $\mathrm{CP}$ sites
T S-R: Soil to root transference

T R-P: Root to aerial parts transference

T S-P: Soil to aerial part transference

CP: Cultivated pastures, NP: Natural pasture

Table 2. Percentage of $\mathrm{Pb}$ transfer from soil to the root, and aerial part of NP and $\mathrm{CP}$ in livestock area near the La Oroya Metallurgical Complex (\%)

$\begin{array}{lrlrrr}\text { Lead transfer } & \text { Average } & \begin{array}{l}\text { Estándar } \\ \text { Deviation }\end{array} & \text { Variance } & \text { Mín. } & \text { Max. } \\ & & & & \\ \text { Soil-root, PN } & 90.29 \mathrm{a} & 30.92 & 955.91 & 50.82 & 143.49 \\ \text { Soil-root, PC } & 76.01 \mathrm{a} & 25.56 & 653.53 & 50.59 & 121.53 \\ \text { Root-aerial part, PN } & 11.68 \mathrm{~b} & 4.81 & 23.19 & 6.33 & 21.60 \\ \text { Root-aerial part, PC } & 13.43 \mathrm{~b} & 4.04 & 16.35 & 6.96 & 18.85 \\ \text { Soil-aerial part, PN } & 9.55 \mathrm{c} & 2.43 & 5.92 & 5.93 & 14.60 \\ \text { Soil-aerial part, PC } & 9.51 \mathrm{c} & 2.25 & 5.05 & 7.01 & 13.96\end{array}$

Average values with different letters vary statistically $(P<0.05)$.

\section{Discussion}

La Oroya soils have received pollution since the metallurgical complex began operations in 1922, and has poured $0.39 \mathrm{Mt}$ of $\mathrm{Pb}$ [36]. In 2008, in La Oroya and Paccha the average concentrations of PM2.5 were 32.4 and $20.3 \mathrm{ug} / \mathrm{m}^{3}$ [37], which exceed the ECA $\mathrm{PM} 2.5=15 \mathrm{ug} / \mathrm{m} 3$ [38], and the average concentrations of PM10 were 52.3 and $42.4 \mathrm{ug} / \mathrm{m}^{3}$, values similar to ECA PM10 = $50 \mathrm{ug}$ $/ \mathrm{m}^{3}$ [38]. At the end of the last century, in La Oroya-Yauli, average values of $\mathrm{Pb}$ in the air were reported exceeding the upper limit by $800 \%\left(1.5 \mathrm{ug} / \mathrm{m}^{3}\right)$. Between 2009 and 2014, reported Pb levels in air were up to three times more than upper limit $[39,40]$.

Heavy metals contaminate water and soil, transfer and bioaccumulate in plants, and affect human and environmental health $[25,26]$.

Accumulated heavy metal contamination for decades in the study area would determine high concentrations of $\mathrm{Pb}$ in the soil, root and aerial part of NP and CP. The soils in the study area have more than 3 times of $\mathrm{Pb}$ than the maximum established in Peru (70 $\mathrm{mg} / \mathrm{kg}$ ) [28] and more than 3.5 times that established in Finland $(60 \mathrm{mg} / \mathrm{kg}$ ) [29]. It is reported that concentrations of $\mathrm{Pb}$ in the soil, between 10 and $30 \mathrm{mg} / \mathrm{kg}$ have no detrimental effects on plant growth [41].

Lead concentration in Paccha community soil is of high risk to human health, because it bioaccumulates in the crops produced. Excess $\mathrm{Pb}$ in soil affects its quality, microbial development and biodiversity [7] and in agri-food products it can cause a series of health problems [42-45].

Average concentration of $\mathrm{Pb}$ in NP and $\mathrm{CP}$ determined in this study (19.46 and $20.73 \mathrm{mg} / \mathrm{kg}$ ), reflects accumulation of $\mathrm{Pb}$ over time, since the smelting began activities in 1922, as reported in other latitudes too [46]. High $\mathrm{Pb}$ content inhibits the absorption of all mineral elements in the plant [47], affects its performance [48], decreases food safety and quality, causing multiple adverse effects on human health $[11,6,15,16]$.

In Caldas-Colombia, the $\mathrm{Pb}$ of soils adjacent to petrochemical activity is transferred and bioaccumulated in brachiaria crops, and the highest levels of $\mathrm{Pb}$ bioaccumulation have the following order: root> stem $>$ leaves $[25,26]$. 


\section{J. Castro et al. / Advances in Science, Technology and Engineering Systems Journal Vol. 5, No. 2, 126-132 (2020)}

Average concentration of $\mathrm{Pb}$ in $\mathrm{NP}$ and $\mathrm{CP}$ in this study was 6.7 times higher than the critical value proposed by other researchers for vegetables $0.05-3.0 \mathrm{mg} / \mathrm{kg}$ [49]. Our results were similar than those observed in pastures areas near to La Oroya reported in a Missouri study [50]. The study soils have a high concentration of heavy metals compared to other parts of Peru and the world, which can lead to unwanted economic and social results.

$\mathrm{Pb}$ concentrations in NP and $\mathrm{CP}$ were similar and consistently higher than those observed in studies conducted in other latitudes $[51,45]$. This study shows that the bioaccumulation of $\mathrm{Pb}$ in the grass roots gives it control over its concentration in the aerial part of the grass. Of $\mathrm{Pb}$ concentration present in the soil, only $9.5 \%$ is transferred to the aerial pasture. Roots capture a large amount of $\mathrm{Pb}$ from the soil (> 83\%), transferring $12 \%$ of $\mathrm{Pb}$ to the aerial part of the plant; However, concentration of $\mathrm{Pb}$ in the edible part of the pasture is a threat of toxicity to high Andean cattle, according to another research [52].

In areas near the refineries, $\mathrm{Pb}$ contents in 31 brachiaria species, is values between 9.8 and $16.0 \mathrm{mg} / \mathrm{kg}$, being higher closer to the emission focus. In places around the exploration wells, $\mathrm{Pb}$ contents between 9.7 and $13.2 \mathrm{mg} / \mathrm{kg}$ are reported [25,26].

Average $\mathrm{Pb}$ in the pastures of the study area was lower than those recorded around sites containing lead slag in Nigeria, forage grasses had between $209-899 \mathrm{mg} / \mathrm{kg}$, with an average of $425 \pm$ $79.0 \mathrm{mg} / \mathrm{kg}$ [53].

Although the average $\mathrm{Pb}$ content in the aerial part of the pastures produced in the study area did not exceed the allowed limit of the European Union $(30 \mathrm{mg} / \mathrm{kg}$ ), it exceeds the normal range of $5-10 \mathrm{mg} / \mathrm{kg}$ recommended by other authors [54]. Considering as a limit value of $\mathrm{Pb}$ in pastures $10 \mathrm{mg} / \mathrm{kg}$ [54], the average of $\mathrm{Pb}$ in pastures of this study was 2 times higher, not being suitable for feeding cattle [55].

Regarding cultivated pastures, in Trifolium alexandrium, Brassica campestris and Avena sativa associations, average concentrations of $\mathrm{Pb}$ was between 36.5 and $60.21 \mathrm{mg} / \mathrm{kg}$ [52], values higher than the European Union toxic level (30 mg / kg) [56], and those found in this study.

In New Zealand pastures, an average value of $\mathrm{Pb}$ is reported in grass $(10.6 \mathrm{mg} / \mathrm{kg})$ with a range of 4.4 to $26.8 \mathrm{mg} / \mathrm{kg}$ [27]; observing that the toxicity of $\mathrm{Pb}$ causes a decrease in the percentage of germination, growth, dry biomass of roots and shoots, alteration of mineral nutrition, reduction in cell division and inhibition of photosynthesis [43,57].

$\mathrm{NP}$ and $\mathrm{CP}$ increase the accumulated amount of $\mathrm{Pb}$ in the root to a higher $\mathrm{Pb}$ content in soil, as observed in another study [58]. Accumulation of $\mathrm{Pb}$ in the aerial part of the grass is also increased to a greater amount of $\mathrm{Pb}$ in soil and root. Comparing the results obtained in both types of pastures, the accumulated amounts of $\mathrm{Pb}$ in the roots and the aerial part were similar in NP and PC. In both types of pasture, the concentration of $\mathrm{Pb}$ in the roots was higher than that of the shoots, which suggests that the transport of lead from the roots to the shoots is restricted and the root maintains a high $\mathrm{Pb}$ content in its structure, and the cumulative amounts of lead in the aerial part of the plants were greater than those reported in other studies [58].

\section{Conclusion}

$\mathrm{Pb}$ concentration was significantly higher in the soil than in the root and aerial part of natural and cultivated pastures used in Andean livestock food -in areas close to metallurgical emissions.

Lead level in soil and grass exceeded the toxic levels suggested by national and international standards; So, the soils and pastures are intoxicated.

The information for the ecosystem studied is useful to take measures to reduce the adverse effects on human health by the consumption of food produced in these soils. This evidence should be used to establish action plans for removal and remediation.

\section{Acknowledgments}

This study was funded by competitive funds from Canon, Sobrecanon y Regalías Mineras administered by the Universidad Nacional del Centro del Perú.

To the authorities of the Comunidad Campesina Purísima Concepción de Paccha-La Oroya, for the facilities in carrying out this study.

\section{Conflict of interest}

All the authors declare that there is no conflict of interests regarding the publication of this manuscript.

\section{References}

[1] Osinergmin. La industria de la minería en el Perú: 20 años de contribución al crecimiento y desarrollo económico del país. Organismo Supervisor de la Inversión en Energía y Minería, 2017. http://www.osinergmin.gob.pe/ seccion/centro_documental/mineria/Documentos/

Publicaciones/Osinergmin-Industria-Mineria-Peru-20anios.pdf.

[2] Suvarapu LN, Baek SO. Determination of heavy metals in the ambient atmosphere: a review. Toxicol. Ind. Health 33, 79-96, 2017. https://doi.org/10.1177/0748233716654827.

[3] Ogabiela EE, Udiba UU, Adesina OB, Hammuel C, Ade-Ajayi FA, Yebpella GG, Mmereole UJ, Abdullahi M. Assessment of metal levels in fresh milk from cows grazed around Challawa industrial Estate of Kano, Nigeria. Journal of Basic and Applied Scientific Research, 1(7): 533-538, 2011.

[4] Castro J, Chirinos D, Tejada de Rivero D. Plomo en la sangre del cordón umbilical y su impacto sobre el peso, longitud, hemoglobina y APGAR en. Revista de Toxicología, 29(0212-7113):100-106, 2012.

[5] Lovell A, Magee N, Nunez S, Mitt K. Biosorption and Chemical Precipitation of Lead Using Biomaterials, Molecular Sieves, and Chlorides, Carbonates, and Sulfates of $\mathrm{Na} \&$ amp; Ca. Journal of Environmental Protection, 4:1251-1257, 2013. https://doi.org/10.4236/jep.2013.411145.

[6] President's Task Force, on Environmental, Health Risks and Safety, \& Risks to Children. Key Federal Programs to Reduce Childhood Lead Exposures and Eliminate Associated Health Impacts, (November): 1-64, 2016. https://portal.hud.gov/hudportal/

documents/huddoc?id=FederalProgramUpdate.pdf.

[7] Rábago I. Capacidad de amortiguación de la contaminación por plomo y cadmio en suelos de la Comunidad de Madrid. Tesis Doctoral. Universidad Complutense de Madrid, 2010.

[8] Nascimento SS, Silva EB, Alleoni LR, Grazziotti PH, Fonseca FG, Nardis BO. Availability and accumulation of lead for forage grasses in contaminated soil. Journal of Soil Science and Plant Nutrition, 14 (4), $783-$ 802, 2014.

[9] Li Y, MCcrory DF, Powell JM, Saam H, Jackson-Smith D. A survey of selected heavy metal concentration in Wisconsin dairy feeds. J. Dairy Sci. $88,2911,2005$

[10] Grytsyuk N, Arapis G, Perepelyatnikova L, Ivanova T, Vynograds'ka V. Heavy metals effects on forage crops yields and estimation of elements accumulation in plants as affected by soil. Science of the Total Environment, 354(2-3), 224-231, 2006. https://doi.org/10.1016/j.scitotenv.2005.01.007 


\section{J. Castro et al. / Advances in Science, Technology and Engineering Systems Journal Vol. 5, No. 2, 126-132 (2020)}

[11] Nava-Ruiz MA. Efectos neurotóxicos de metales pesados (cadmio, plomo, arsénico y talio). Arch Neurocien (Mex), 16(3), 140-147, 2011.

[12] Castro J, Chirinos Peinado D, Ríos E. Lead content and placental weight and its association with gestational age, weight, length and hemoglobin in newborns of metallurgical region-Peru. Revista de Toxicologia, 33(2), 2016.

[13] Singh MK, Jha D, Jadoun J. Assessment of Physico-chemical Status of Groundwater Samples of Dholpur District, Rajasthan, India. International Journal of Chemistry, 4(4), 96-104, 2012. https://doi.org/10.5539/ijc.v4n4p96

[14] Tchounwou P, Yedjou C, Patlolla A, DJS. Heavy Metals Toxicity and the Environment. NIH Public Access, (EXS. 2012; 101: 133-164, 2014. https://doi.org/10.1007/978-3-7643-8338-1.

[15] Tepanosyan G, Maghakyan N, Sahakyan L, Saghatelyan A. Heavy metals pollution levels and children health risk assessment of Yerevan kindergartens soils. Ecotoxicology and Environmental Safety, 142, 257-265, 2017. https://doi:10.1016/j.ecoenv.2017.04.013

[16] Tepanosyan G, Sahakyan L, Belyaeva O, Maghakyan N, Saghatelyan A. Human health risk assessment and riskiest heavy metal origin identification in urban soils of Yerevan, Armenia. Chemosphere, 184, 1230-1240, 2017. https://doi.org/10.1016/j.chemosphere.2017.06.108

[17] Olayinka OO, Akande OO, Bamgbose K, Adetunji MT. Physicochemical Characteristics and Heavy Metal Levels in Soil Samples obtained from Selected Anthropogenic Sites in Abeokuta, Nigeria. J. Appl. Sci. Environ. $\begin{array}{lllll}\text { Manage. } & \text { Vol. } 21 & \text { (5):883-891, } 2017 . & \text { DOI: }\end{array}$ https://dx.doi.org/10.4314/jasem.v21i5.14

[18] Harmanescu M, Alda L, Bordean D, Gogoasa I, Gergen I. Heavy metals health risk assessment for population via consumption of vegetables grown in old mining area; a case study: Banat County, Romania. Chemistry Central Journal, 5(1), 64, 2011. https://doi.org/10.1186/1752-153X-5-64.

[19] Rim-Rukeh A. Uptake of Heavy Metals by Okro (Hibiscus Esculentus) Grown on Abandoned Dump Sites in Effurun, Nigeria. Journal of Emerging Trends in Engineering and Applied Sciences (JETEAS) 3 (4): 640-644, 2012.

[20] Papaioannou D, Kalavrouziotis IK, Koukoulakis PH, Papadopoulos F, Psoma P. Interrelationships of metal transfer factor under wastewater reuse and soil pollution. Journal of Environmental Management, 1-9, 2017. https://doi.org/10.1016/j.jenvman.2017.04.008.

[21] Bu-Olayan AH, Thomas BV. Combined effects of particulates dispersion and elemental analysis in desert plants: a modeling tool to air pollution. International Journal of Environmental Science and Technology, 13(5), 1299-1310, 2016. doi:10.1007/s13762-016-0968-5.

[22] Kachenco, A.G., Singh, B. Heavy metal contamination in vegetables grown in urban and metal smelter contaminated sites in Australia. Water Air Soil Pollut. 169, 101e123, 2006.

[23] Alvarez-Berríos N, Campos-Cerqueira M, Hernández-Serna A, Delgado A, Román-Dañobeytia F. Impacts of small-scale gold mining on birds and anurans near the Tambopata Natural Reserve, Peru, assessed using passive acoustic monitoring. Tropical Conservation Science, 9(2), 832-851, 2016. https://doi.org/10.1177/194008291600900216.

[24] Barrios-Napuri C. El desarrollo empresarial desde la perspectiva local. España: Red Académica Iberoamericana Local Global. Universidad de Málaga, 2008. http://www.eumed.net/libros-gratis/2008b/403/index.htm.

[25] Peláez-Peláez MJ. Evaluación del estrés abiótico en Brachiaria spp. inducido por bioacumulación de cadmio y plomo, en una zona aledaña al corredor petrolífero de Barrancabermeja (Colombia). Tesis Doctoral. Universidad Nacional de Colombia, 2016.

[26] Peláez-Peláez MJ, Bustamante CJ, Gómez LE. Presencia de cadmio y plomo en suelos y su bioacumulación en tejidos vegetales en especies de Brachiaria en Magdalena medio colombiano. Revista.luna.azúl. 43:82-101, 2016.

[27] Martin AP, Turnbull RE, Rissmann CW, Rieger P. Heavy metal and metalloid concentrations in soils under pasture of southern New Zealand. Geoderma Regional 11,18-27, 2017. https://doi.org/10.1016/j.geodrs.2017.08.005

[28] MINAM. DS N011-2017-MINAM. "Aprueban Estándares de Calidad Ambiental (ECA) para Suelo. Perú: El Peruano, 2017.

[29] Ministry of the Environment, Finland. Government Decree on the Assessment of Soil Contamination and Remediation Needs 214/2007, March 1, 2007. Ministry of the Environment, Finland.

[30] MINAM. Guía para muestreo de suelo, 72, 2014. http://www.minam.gob.pe/calidadambiental/wpcontent/uploads/sites/22/2013/10/GUIA-PARA-EL-MUESTREO-DESUELOS-final.pdf

[31] Li, F., Huang, J., Zeng, G. et al. Toxic metals in topsoil under different land uses from Xiandao District, middle China: distribution, relationship with soil characteristics, and health risk assessment. Environ Sci Pollut Res 22, 12261-12275, 2015. Doi:10.1007/s11356-015-4425-7

www.astesj.com
[32] Li F, Zhang J, Huang J, Huang D, Yang J, Song Y, Zeng G. Heavy metals in road dust from Xiandao District, Changsha City, China: characteristics, health risk assessment, and integrated source identification. 2016. Environ Sci Pollut Res Int. 23(13):13100-13, 2016. Doi: 10.1007/s11356-016-6458-

[33] García-Gallegos E, Hernández-Acosta E. García-Nieto E, AcevedoSandoval O. Contenido y traslocación de plomo en avena (Avena sativa L.) y haba (Vicia faba L.) de un suelo contaminado. Revista Chapingo Serie Ciencias Forestales y del Ambiente 17(1):19-29, 2011. DOI: https:// doi.org/10.5154/r.rchscfa.2010.02.002.

[34] EPA. Method 3050B: Acid digestion of sediments, sludges, and soils. Revision 2, 1996 https://www.epa.gov/sites/production/files/201506/documents/epa-3050b.pdf

[35] Mertens D. AOAC Official Method 975.03. Metal in Plants and Pet Foods Official Methods of Analysis, 18th edn. Editors: Horwitz W, and GW Latimer. Chapter 3, pp 3-4, AOAC-International Suite 500, 481. North Frederick Avenue, Gaitherburg, Maryland. USA, 2005.

[36] Díaz W. Estrategia de gestión integrada de suelos contaminados en el Perú. Revista del Instituto de Investigación, FIGMMG-UNMSM 19 (38):103-110, 2016.

[37] Arotoma KS. Distribución de las fuentes del material particulado en la zona alta y media de la cuenca del Mantaro - ciudades de Huancayo, Jauja, Junín, Concepción, La Oroya, Paccha. Respositorio UAP,2014. https://vdocuments.es/tesiscomposicionqcaaerosolesuap.html.

[38] MINAM. Decreto Supremo No 003-2008-MINAM. Aprueban los estándares nacionales de calidad ambiental para aire. Lima 21 de agosto de 2008.

[39] Doe Run Perú. Historia de la empresa. 2019 http://www.doerun.com.pe/content/pagina.php?pID=124. Tomado el $19 \mathrm{de}$ abril 2019.

[40] SPDA. La Oroya: registraron metales pesados en el aire cuando el complejo metalúrgico no operaba. SPDA Actualidad Ambiental. 2016. http://www.actualidadambiental.pe/?p=35070.

[41] Mlay PS, Mgumia Y. Levels of lead and copper in plasma of dairy cows, pastures, soil and water from selected areas of Morogoro suburbs, Tanzania. Livestock Research for Rural Development. Volume 20, Article \#60, 2010. http://www.lrrd.org/lrrd20/4/mlay20060.htm.

[42] Ma W. Lead in mammals, environmental contaminants in biota. CRC Press, pp 595-607, 2011.

[43] Sharma P, Dubey RS. Lead toxicity in plants. Braz J Plant Physiol 17:35-52, 2005

[44] Rodrigues SM, Pereira ME, Duarte AC, Römkens PF. Soil-plant-animal transfer models to improve soil protection guidelines: A case study from Portugal. Environment International, 39(1),27-37, 2012. https://doi.org/10.1016/j.envint.2011.09.005.

[45] Reiser R, Simmler M, Portmann D, Clucas L, Schulin R, Robinson B. Cadmium concentrations in New Zealand pastures: relationships to soil and climate variables. J. Environ. Qual. 43 (3), 917-925, 2014.

[46] Wuana RA, Okieimen FE. Heavy metals in contaminated soils: a review of sources, chemistry, risks and best available strategies for remediation. ISRN Ecology Volume 2011, Article ID 402647, 20 pages. http://dx.doi.org/10.5402/2011/402647

[47] Yilmaz K, Akinci IE, Akinci S. Effect of lead accumulation on growth and mineral composition of eggplant seedlings (Solarium melongena). New Zealand Journal of Crop and Horticultural Science, 37(3), 189-199, 2009. https://doi.org/10.1080/01140670909510264.

[48] Alloway B. Heavy Metals in Soils:Trace Metals and Metalloids in Soils and Their Bioavailability. Environmental Pollution, Springer Science+Busines Media Dordrecht, 2013. https://doi.org/10.1007/978-94-007-4470-7.

[49] Tokaliog lu Ş, Kartal Ş, \& Güneş A. Determination of Heavy Metals in Soil Extracts and Plant Tissues at Around of a Zinc Smelter. Int. J. Environ. Analyt. Chem. 80(3):201-217, 2001. Doi:10.1080/03067310108044370

[50] Proyecto El Mantaro Revive. 2012. Resultados de la evaluación de la calidad de suelo de la zona alta y media de cuenca del río Mantaro - Perú. Cáritas Huancayo. https://es.slideshare.net/ElMantaroRevive/el-mantaro-reviveresultados-de-la-evalucin-de-la-calidad-de-suelo-de-la-zona-alta-y-mediade-cuenca-del-ro-mantaro-per.

[51] Longhurst RD, Roberts AH, Waller JE. Concentrations of arsenic, cadmium, copper, lead, and zinc in New Zealand pastoral topsoils and herbage. New Zeal. J. Agr. Res. 47 (1), 23-32, 2004

[52] Iqbal Z, Ahmad K, Aisha N, Mustafa I, Ibrahim M, Fardous A, Gondal S, Hussain A, Arshad F, Rasul I, Yousaf M, Fawad A, Sher M, Hussain A, Ahmad H, Rashid U. Heavy Metals Concentration in Soil-Plant-Animal Continuum under Semi-Arid Conditions of Punjab, Pakistan. Pakistan J. Zool., vol. 47(2), pp. 377-382, 2015. 
[53] Ogundiran MB, Ogundele DT, Afolayao PG, Osibanjo O. Heavy MetaLs Levels in Forage Grasses, Leachate and Lactating Cows Reared around Lead Slag Dumpsites in Nigeria. Int. J. Environ. Res. 6(3):695-702, 2012.

[54] Kabata-Pendias A, Pendias H. Trace Elements in Soils and Plants. 4th ed. CRC Press Inc. 548 Pages, 2010. ISBN 9781420093681. https://doi.org/10.1201/b10158

[55] Shah FU, Ahmad N, Masood KR, Peralta-Videa JR, Ahmad FD. Heavy Metal Toxicity in Plants. Plant Adaptation and Phytoremediation, 71-97, 2010. doi:10.1007/978-90-481-9370-7 4.

[56] Oficial Journal of the European Union. Directiva 2005/87/CE de la Comisión por la que se modifica el anexo I de la Directiva 2002/32/CE del Parlamento Europeo y del Consejo, sobre sustancias indeseables en la alimentación animal, en lo referente al plomo, el flúor y el cadmio. 2005. https://www.boe.es/doue/2005/318/L00019-00024.pdf.

[57] Ekmekci Y, Tanyolac D, Ayhan B. A crop tolerating oxidative stress induced by excess lead: maize. Acta Physiol Plant 31:319-330, 2009.

[58] Win Mi Htwe, Yin Yin Kyawt, Sarayut Thaikua, Yuriko Imai, Susumu Mizumachi and Yasuhiro Kawamoto. Effects of lead contamination in soils on dry biomass, concentration and amounts of lead accumulated in three tropical pasture grasses. Japanese Society of Grassland Science, Grassland Science, 62, 167-173, 2016. https://doi.org/10.1111/grs.1212. 